\title{
Potentials and Challenges for Community Based Ecotourism Development at Haro Aba Diko Controlled Hunting Area, South Western Oromia
}

\author{
Habib Bati Geda $^{1^{*}} \quad$ Fanuel Kebede $(\mathrm{PhD})^{2} \quad$ Dereje Denu(PhD $)^{3}$ \\ 1.Department of Ecotourism and Biodiversity conservations,Bedele college of Agriculture and Forestry,Mettu \\ university,Ethiopia \\ 2.Ethiopian Wild life conservation Authority \\ 3.Department of Biology, Jimma University, Ethiopia
}

\begin{abstract}
This study was conducted to identify the potentials, Challenges of community- based ecotourism at Haro Aba Diko Controlled Hunting area, South western Ethiopia. Community -based ecotourism has become the most basic tool to meet livelihood demand across the world. Primary and secondary data were used for this study. Purposive and simple random sampling methods were used to select kebeles and 140 sample respondents respectively. To select key informant snowball method was used. Quantitative data was analyzed using frequency, percentage and mean whereas the qualitative data was used to triangulate and authenticate the study. The result of the study indicated that Haro Aba Diko Controlled Hunting area had huge resource potentials such as attractive flora and fauna ,Dabena and Didesa river with attractive cultural resource like Cultural dance, cultural food and drinks .Having this potentials community based ecotourism establishment is constrained by lack of awareness, basic infrastructures, tourism professionals and Illegal activity of community like Settlements within the Controlled Hunting Area and Conversions of forest lands to Agricultural lands. To empower the establishment of community based ecotourism, awareness creation program, promotion activity, filling gap of community social infrastructures and further study in the study area should be needed.
\end{abstract}

Keywords: Community -based, Ecotourism, Challenges, Potentials

DOI: $10.7176 / \mathrm{JRDM} / 68-01$

Publication date:August $31^{\text {st }} 2020$

\section{INTRODUCTION}

\subsection{Background and Justifications}

Tourism is the major and fastest-growing industries in the world. It is an increasingly vital source of income, employment and wealth in many countries. Today tourism accounts for a larger share of foreign exchange earnings and export earnings than any other industry in the world. The contribution of tourism industry to the global economy has grown fast in recent years. It has become one of the leading foreign exchange earnings for many countries.With a growing interest to spend leisure time in nature and growing awareness of environmentalism, ecotourism has become one of the fastest-growing sectors of the tourism industry.(TIES, 2016), reported that ecotourism provides better sectoral linkages, reducing leakage of benefits out of the country, creating local employment and fostering sustainable development. It has been promoted as a means of reconciliation biodiversity conservation with economic development, mainly in developing countries. The International Ecotourism Society (2010) described ecotourism as responsible travel to natural areas that conserve the environment and enhance the well-being of local communities.

Community-based ecotourism is a type of ecotourism in which the community has significant control over it, and the majority of the benefits remain in the community. It has emerged as a tool for poverty alleviation, wildlife conservation and the distribution of responsible and sustainable tourism offerings Aregawi,( 2016). Ethiopia is having huge potential of ecotourism resource counting cultural, historical, archaeological and natural resources which are ideal for the development of sustainable ecotourism ventures (Ketema, 2015). There are some encouraging community-based ecotourism developments in Ethiopia such as Adaba-Dodola, a pilot ecotourism project on Semen Mountains National Park, Wonchi Crater Lake (near Ambo, Oromia Region), Adwa (Tigray region) and Mekit in north Wollo (Amahara region) Maggie (2016) The challenges facing the tourism industry are complex and numerous like: lack of tourism infrastructures,lack of financial support for tourism sectors and lack of promotions for tourism destinations. Since, tourism sector is very recent, most of the local communities are not aware of about its economic, social, cultural and environmental benefits. As a result some of the members of local community do not support community based ecotourism projects. Community based projects have failed, usually because of lack of financial viability Mulugeta, (2011).

Besides of this when the NGOs fully implement the project and hands over management to the community, the project can easily fail because there has not been either initial or sustained support on the part of the community.involving local community in planning the project makes the community develop sense of ownership 
which is a guarant for the success of that project.Mulugeta,Fisseha.(2012). lack of basic ecotourism infrastructure and facilities, conflicts of interest over resource usage and a lack of trained man power are the major hindrances of communitybasedecotourism development in Ethiopia Sewnet (2017) . Moreover; Habte ( 2015) also indicated that due to lack of biodiversity data, the biodiversity potential of the area is unknown.

There was no study conducted in Haro Aba Diko Controlled Hunting area to identify the potentials resource and challenges that limit the foundation of community based ecotourism else before, except the research conducted by Habte (2014 and 2015)on pilot socio-economic analysis and Community education to conserve Wildlife through the use of local resource,identified lack of community awerness and initiated natural resource conservations through participatory approach to conserve their natural resource.

Therefore this study investigated to fill such knowledge gaps on tourism in general and community based ecotourism in particular.

\section{MATERIALS AND METHODS}

\subsection{Description of the study area}

\subsubsection{LOCATION}

The study was conducted at Haro Aba Diko Controlled Hunting area, south western of oromia region, Bunno Bedele Zone. It is bounded by Dabo Hana, Chewaka and Meko woredas. The area is administered under Oromia Forest and Wild life Enterprise having an area of 21,000 hectares.
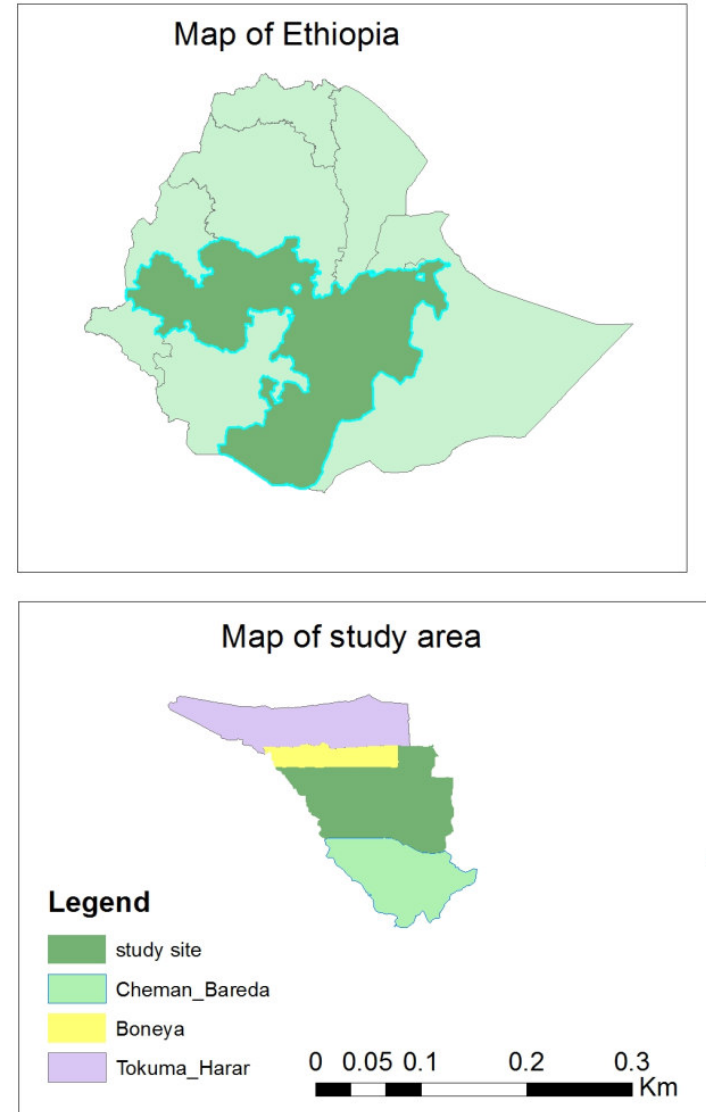

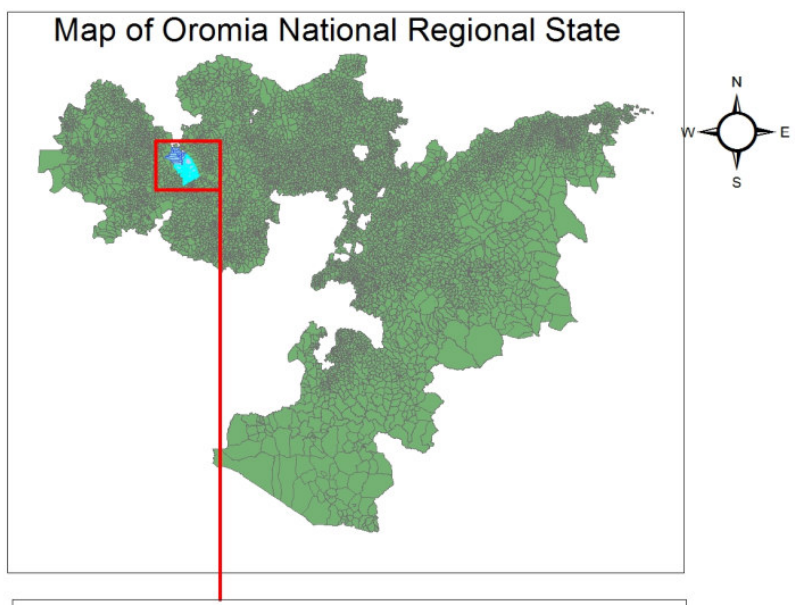

Map of the two woredas of Buno Bedele Zone

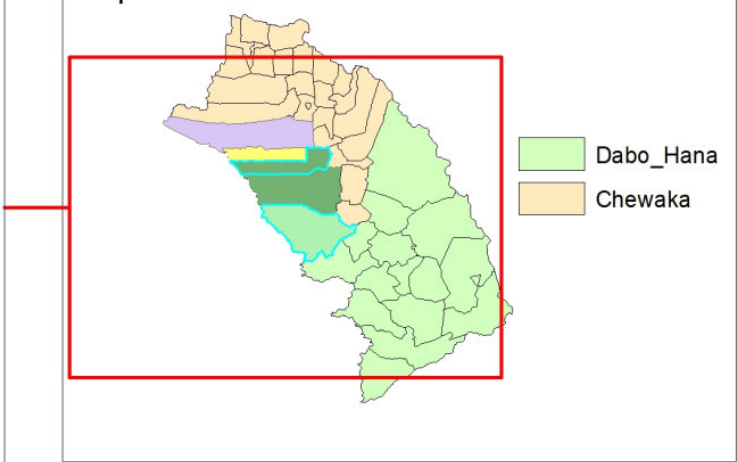

Figure 1: Map of study area showing Ethiopia, Oromia Regional State and the sudy site

\subsubsection{Human Population}

Based on the 2007 census The projected population of Dabo Hana and Cheweka woredas was 123,855 and 168318 respectively in 2017. Of this, 61413 were male and 62442 were female in Dabo Hana and 89043 were male and 79275 were females in Cheweka woreda. About $10 \%$ of Dabo Hana and $2 \%$ of Cheweka woreda populations were urban dwellers.

\subsubsection{CLIMATE}

The area grouped in to three climatic zones based on altitude. There are two distinct seasons: the rainy season starting in late March and ending in October and the dry season occurring during November to early March and Chewaka and Dabo Hana woreda receive average annual rainfall of $1100 \mathrm{~mm}$ and $1131 \mathrm{~mm}$ respectively. Dabo Hana and Cheweka woredas have the minimum and maximum daily temperature of $18-24^{\circ}$ and $36-41^{\circ}$ respectively (LDMA, 2010 ). 


\subsubsection{Socio-economic conditions of surrounding community}

The community surrounding the area practice mixed farming mode of life. Different kinds of crops, vegetables, livestock, oil crops and coffee are under production in the woreda. Coffee and Khat, teff and maize are an important cash crop of the area.

\subsection{Research Methods}

\subsubsection{Study site selections and Sampling design}

The rational for selecting Haro Aba Diko Controlled Hunting area was the presence of various potential resource for community -based ecotourism development .Mixed research approach is used employing both probability and non-probabilty sampling methoth,Purposive, simple random sampling and snowball methods were used to select kebeles, Respondents and key informants respectively. The respondents from households of local communities were selected randomly from three Kebeles surrounding Haro Aba Diko Controlled Hunting (HADCH) area using probability sampling methods. Kebeles were selected from Dabo Hana and Cheweka woredas by purposive sampling technique. Two kebeles (Tokuma Harar and Boneya) from Cheweka and one kebele(Chemen Bereda) from Dabo Hana Woreda were selected based on their proximity. Among 1384 house holds of three kebeles a total sampled households of 492,514 and 378 from Chemen Bereda,Tokuma Harar and Boneya kebeles respectively were selected and 140 respondents were selected among House-holds randomly based on the formula of (Israel, 1992),

$$
n=\frac{N}{1+N(e) 2}=\frac{1384}{1+1384(0.08) 2}=140
$$

where:

$\mathrm{n}=$ sample size required

$\mathrm{N}=$ number of people in the population

$\mathrm{e}=$ the precision level which is $=( \pm 8 \%)$

Where Confidence Level is $95 \%$ at $\mathrm{P}= \pm 5$ (maximum variability)

\subsubsection{Methods of Data Collections}

To undertake this study, both primary and secondary data were used by employing both qualitative and quantitative. The primary data was collected using a structured questionnaire that was administered by the researcher. The questionnaire was pre-tested and a necessary correction was made before actual use. During the interview, the researcher provided enough information about the objectives of the study to avoid potential bias from the respondents in responding to questions. Secondary data were collected from relevant sources such as from bureau of Oromia Forest and wildlife enterprise of the Bunno Bedelle Zone, Ministry of Culture and Tourism bureau of the zone as well the woreda and Agricultural and rural development office of Dabo Hana and Cheweka woreda to verify the primary data, in addition secondary data from literature review and previously published research and articles was also used.

\subsubsection{Interview}

Interview were conducted with Community representatives, controlled hunting area warden, staff members of cultural and tourism bureau and Oromia forest and wildlife enterprise of the zone and woredas. To do these a list of questions were prepared and respondents were interviewed to forward their ideas, opinions, feelings and knowledge regarding the challenges and opportunity for developing community based ecotourism at Haro Aba Diko Controlled Hunting Area, role of community to conserve biodiversity and their responsibility to establish community based ecotourism in Haro Aba Diko Controlled Hunting area and their attitude towards biodiversity in general and community based ecotourism concept in particular were part of interview questions (Annex III).

\subsubsection{Focused group discussion}

Focus group discussions were carried out with local elders, community leaders, including individuals who have adequate knowledge of controlled hunting area (Figure 5). The issues discussed include the potential resource for community based ecotourism and challenges of Community- based ecotourism in Haro Aba Diko Controlled Hunting area, role of government and community to develop community-based ecotourism in the study area, expectations and attitudes of community towards community- based ecotourism, benefit the area provide for the surrounding community, weather community has been taken any training concerning awareness creations program and biodiversity issues in general and community based ecotourism in particular, were some of the points discussed with the community during the study period (Annex II). 

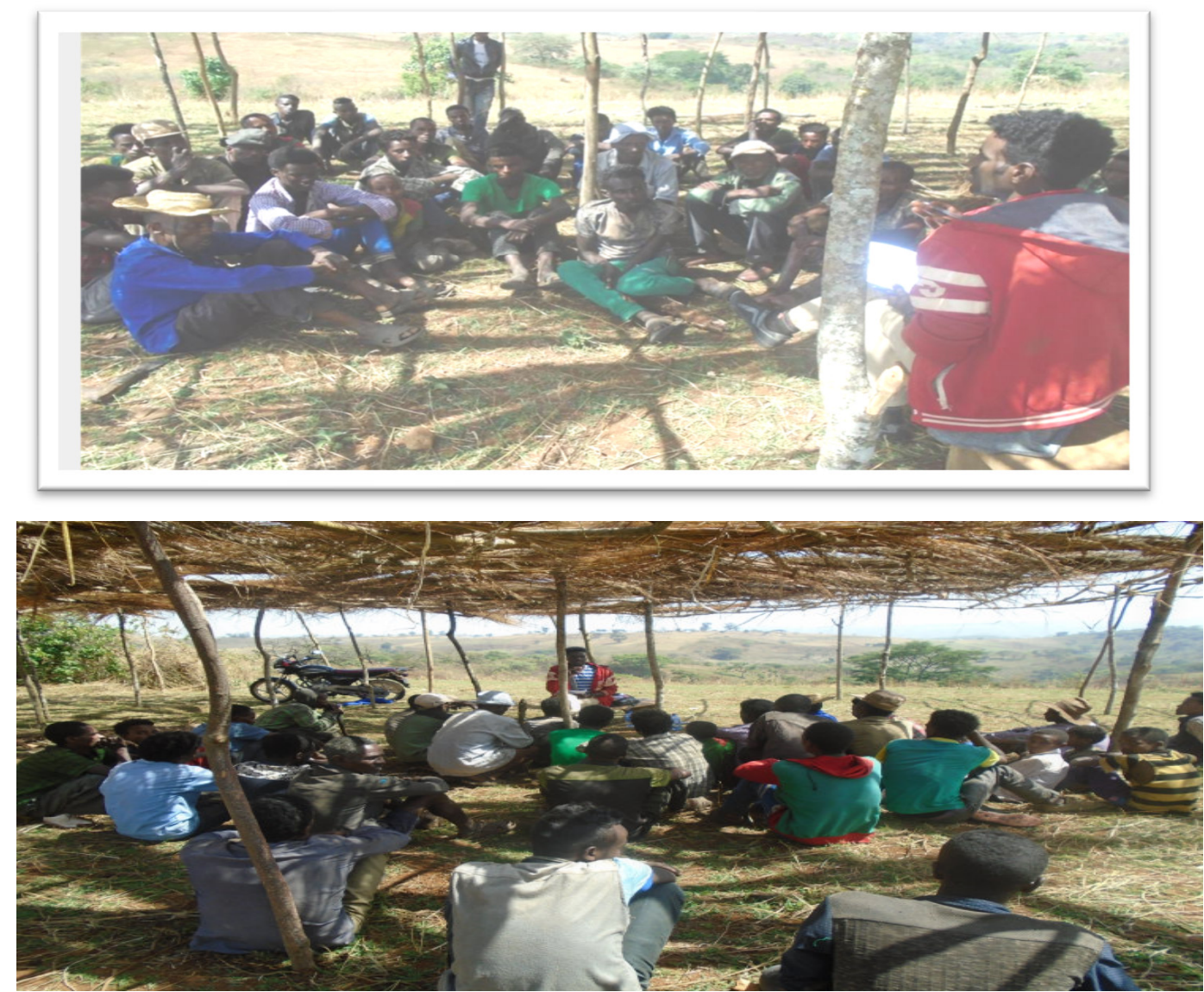

Figure 2: Discussions with local community surrounding Haro Aba Diko Controlled Hunting area 3.2.2.3. Questionnaire surveys

Questionnaire survey was carried out with respondents to gather data on socioeconomic characteristics, potential resource of Haro Aba Diko Controlled Hunting area and challenges hinders to establish community-based ecotourismas well as community perceptions and prospects towards community based ecotourism and benefit the area provide for community surrounding the area, major cause for the destructions of the area resource and appropriate solutions to overcome the destructions of resource were conducted within selected respondents from three kebeles of Chemen Bereda, Tokuma Harar and Boneya surrounding controlled hunting area (Annex I).

\subsubsection{Key informants interview}

Key informant interview were carried out with 10 respondents purposely taken through snowball methods these were, two controlled hunting area scouts, community leader of Chemen Bereda Tokuma Harar and Boneya kebeles, manager of Oromia Forest and wild life Enterprise, staff member of Oromia Forest and wild life Enterprise, manager of tourism bureau of zone and Dabo Hana and Cheweka district to collect reliable information about potential resource of Haro Aba Diko Controlled Hunting area like wild life, types of vegetations found in the area and different water body available in the area, challenges limit to establish community -based ecotourism in the area and opportunity of community- based ecotourism in Haro Aba Diko Controlled Hunting area and year when the area is established were the questions asked (Figure 6) 

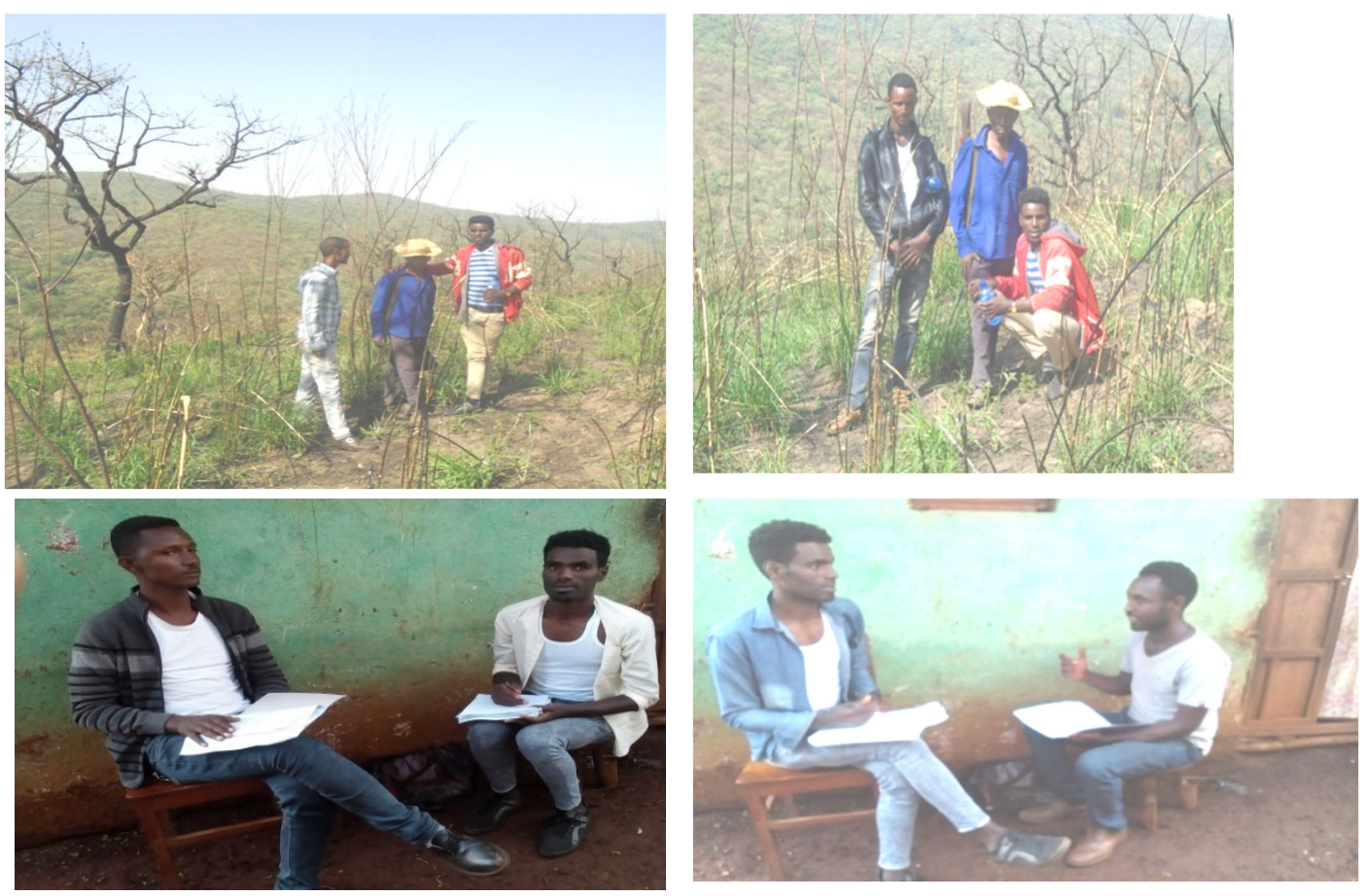

Figure 3: Key informant interview with some selected key informants

\subsubsection{Field observation}

Observation was the main instrument of data collection applied during area visitation to observe the condition of biodiversity, potential resource for ecotourism and obstacles of community based ecotourism in and the surroundings of Haro Aba Diko Controlled Hunting area. In addition infrastructure facilities and life style of the local people surrounding controlled Hunting area was observed during area visitations. To capture information, Note book and photo camera were used.Field observations were conducted together with HADCHA warden in order to get better understanding of the information collected (Figure 7) below.
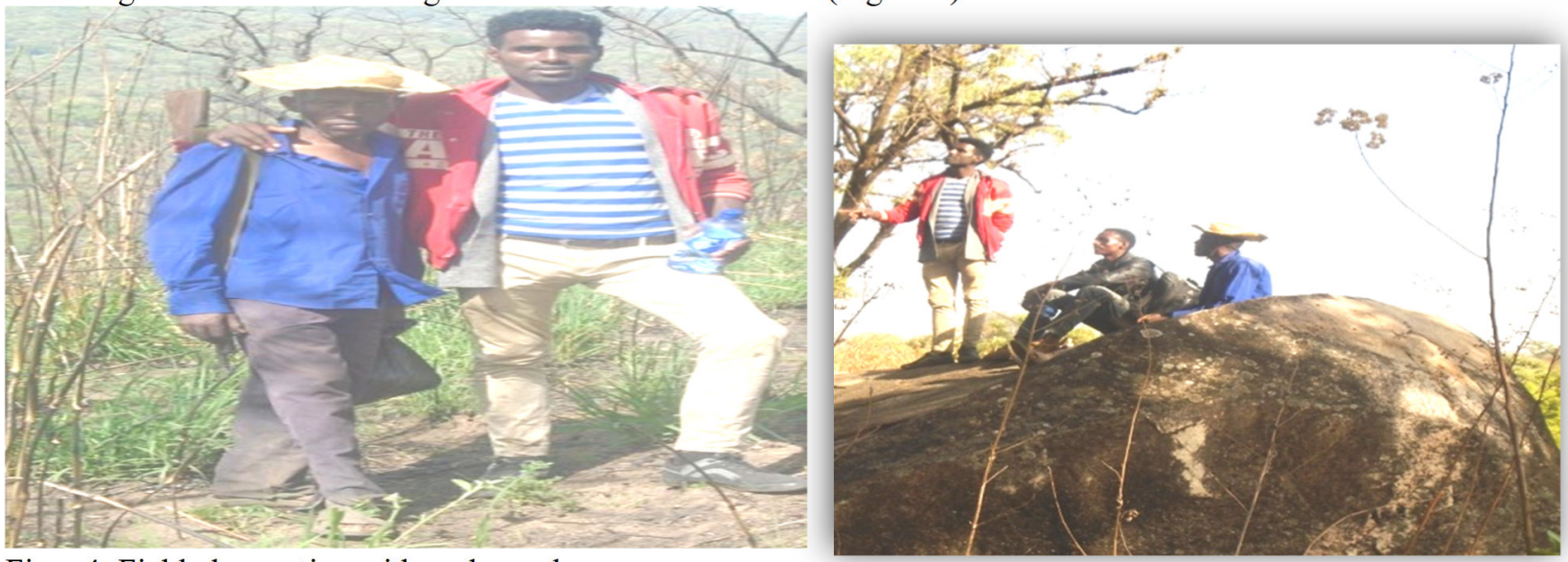

Figre 4: Field observation with park warden

\subsection{METHODS OF DATA ANALYSIS}

Data analyses were done both quantitatively and qualitatively. The data gathered by questionnaire was first arranged and organized in tables and changed into frequency and percentage, and then it is classified and tabulated. Multiple response questions were presented in multiple response tables, considering both total number of people and total responses percentages, SPSS statistics version 23 was used for performing percentage, frequency, tables and graphs (bar charts) to show results as well as Cross tabulation and chi-square methods were used in order to find out the degree of association of each independent variable to the dependent variables and variations among variables. Text explanations and descriptions were used in case of qualitative data analysis. Data collected through interview were analyzed systematically based on the techniques of listening and transcription, reduction to units of relevant meaning and summarization. Data collected through focused group discussion was critically analyzed by using the guidelines which was used for analyzing interview responses. Data collected through field observation was analyzed in the form of text. 


\section{RESULT AND DISCUSSIONS}

\subsection{Community Source of income.}

In order to identify the major source of income, basic data were collected from the respondents. Based on their response crop farming, livestock rearing, mixed farming (both livestock rearing and crop farming) and other income generating activities like handcraft and bee keeping activities are the major source of their income as indicated in (Figure 5) below.

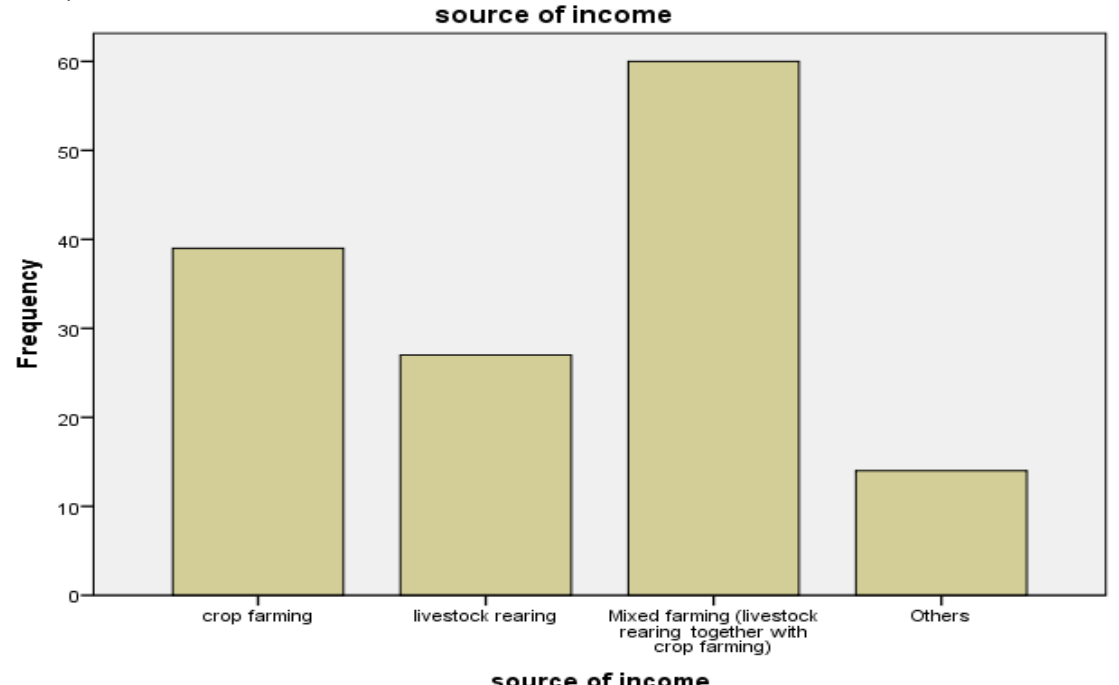

Figure 5: Income Source of Community

Concerning community source of income $42.9 \%$ respondent mentioned that mixed farming (both crop farming and livestock rearing) is their income generating activity and crop farming accounts $27.9 \%$ and the rest of them practice livestock rearing and other income generating activities like handicrafts and bee keeping activities contributed $19.3 \%$ and $10.0 \%$ respectively. Human population increase, need of grazing land and agricultural expansion will negatively affect the (HADCHA) unless other alternative income generating activity like community- based ecotourism is established in the area ,the potential resource of the area destructed by over grazing, settlement, and farm land expansion.

\subsection{Natural resource for Community- based ecotourism development}

The survey results of the respondents shows that Haro Aba Diko Controlled Hunting area has sufficient natural resource for community based ecotourism developments $.40 .71 \%$ of respondents mentioned that the presence of dense attractive natural forest that is habitat for diversified wild life species and $32.14 \%$ of respondents revealed the existence of Mammal species ranges from small mammals to large mammals. The rest $14.29 \%, 8.57 \%$ and $4.9 \%$ of respondents mentioned the presence of different rivers like Dabena, Didesa, that is potential source of fish species , scenic mountains that is having good climatic conditions and hot spring that is used to cure desease. This indicated that Presence of this natural resource is the base for community -based ecotourism development .However it need effective management and promotions (Figure6).

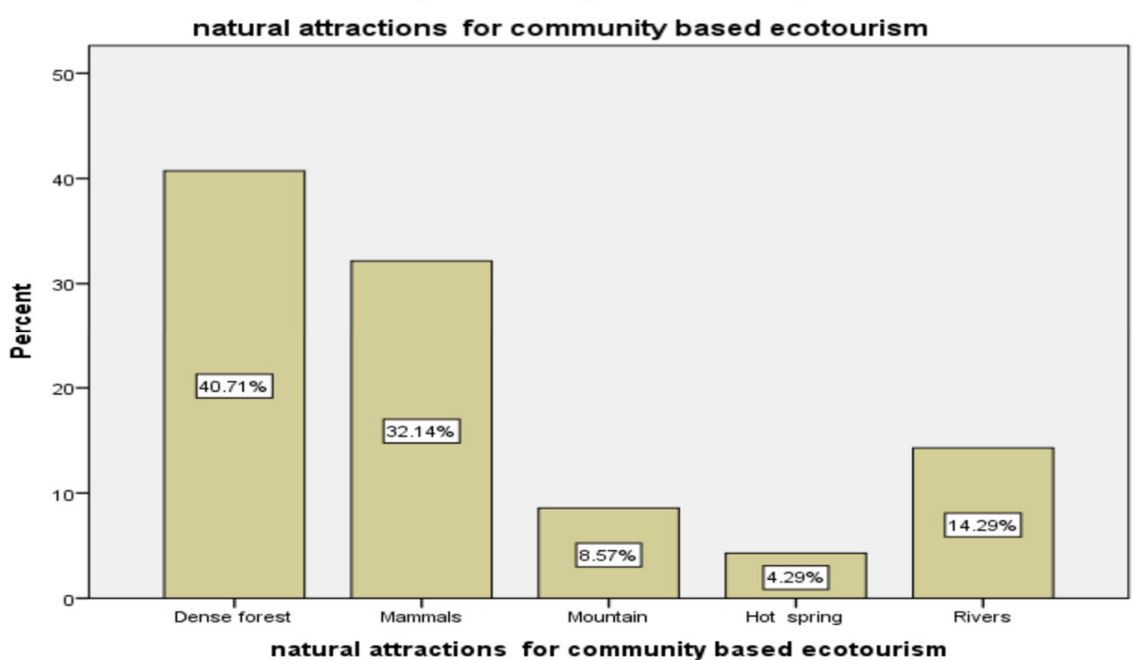

Figure 6: Natural resource for community-based ecotourism 


\subsubsection{Fauna in Haro Aba Diko Controlled Hunting Area.}

List of fauna found in Haro Aba Diko Controlled Hunting area with their local, common and scientific name (Table 1).

\begin{tabular}{|lll|}
\hline Local name & Common name & Scientific name \\
\hline Hoola Bishaanii & Waterbuck & Kobus ellipsiprymnus \\
\hline & & Panthera leo \\
\hline Leencaa & Lion & Potamochoerus larvatus \\
\hline Booyyee adii & Bush pig & Potamochoerus larvatus \\
\hline Boyye gurachaa & Common bush pig & Panthera pardus \\
\hline Qeeransaa & Leopard & Colubes gureza \\
\hline Weenii adii & Colubes monkey & (Phacochoerus aethiopicus), \\
\hline Karkarroo & Warthog & Hippopotamus amphibious \\
\hline Roobii & Hipopotamus & Papio Anubis \\
\hline Jaldeesaa & Baboon & Equus quagga \\
\hline Harre Didaa & Plain Zebra & Syncerus caffer \\
\hline Gafarsaa & Buffalo & Swlvicapra grimmia \\
\hline Kurruppee & Bush duiker & Oreochomis niloticus \\
\hline Qurxummii & Tilapia fish & Cercopiticus mitis \\
\hline Caanaa & Blue monkey & Cercopithecus neglectus \\
\hline Hamaa & De Brazza's Monkey & Papio Anubis \\
\hline Jaaldessa & Olive Baboon & Hylochoerus meinertzhageni \\
\hline Qamaalee & Grivet Monkey & Canis aureus \\
\hline Gadamsa & Giant Fores & Orycteropus afer \\
\hline & Greater kudu & \\
\hline & & \\
\hline & Dik Controlled & Soln \\
\hline
\end{tabular}

Table 1:Fauna in Haro Aba Diko Controlled Hunting area. Source :Habte ( 2015).

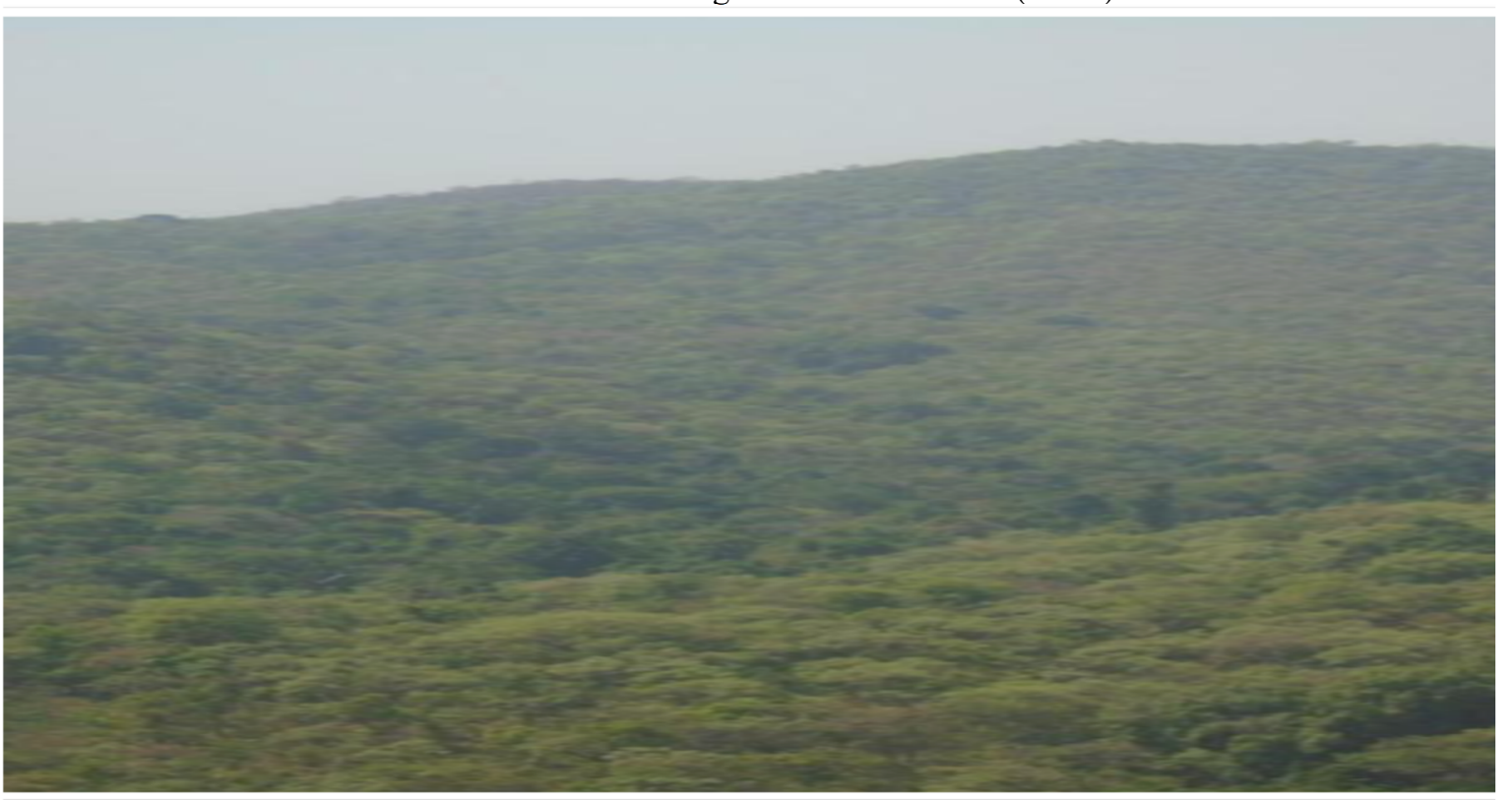

Figure 7:Partial view of forest in Haro Aba Diko Controlled Hunting area

\subsection{Cultural resource for Community -based ecotourism development}

The survey result of the study showed that Haro Aba Diko Controlled Hunting Area has different cultural resources that are the base for the community-based ecotourism development. $34.29 \%$ of respondents revealed the presence of delicious cultural food and drinks. $29.29 \%$ of the respondents confirmed the presence of different Artifacts practiced by local community. $24.29 \%$ of respondents suggested the presence of traditional dance with traditional dressing style . $(6.43 \%)$ of respondents mentioned the presence conflict resolution mechanisms through local institutions(Jaarsummaa) ).where as $5.71 \%$ of respondents replied the presence of other cultural practice like 
coffe ceremony,Irrecha ceremony, Buna Qala, (Figure 8).

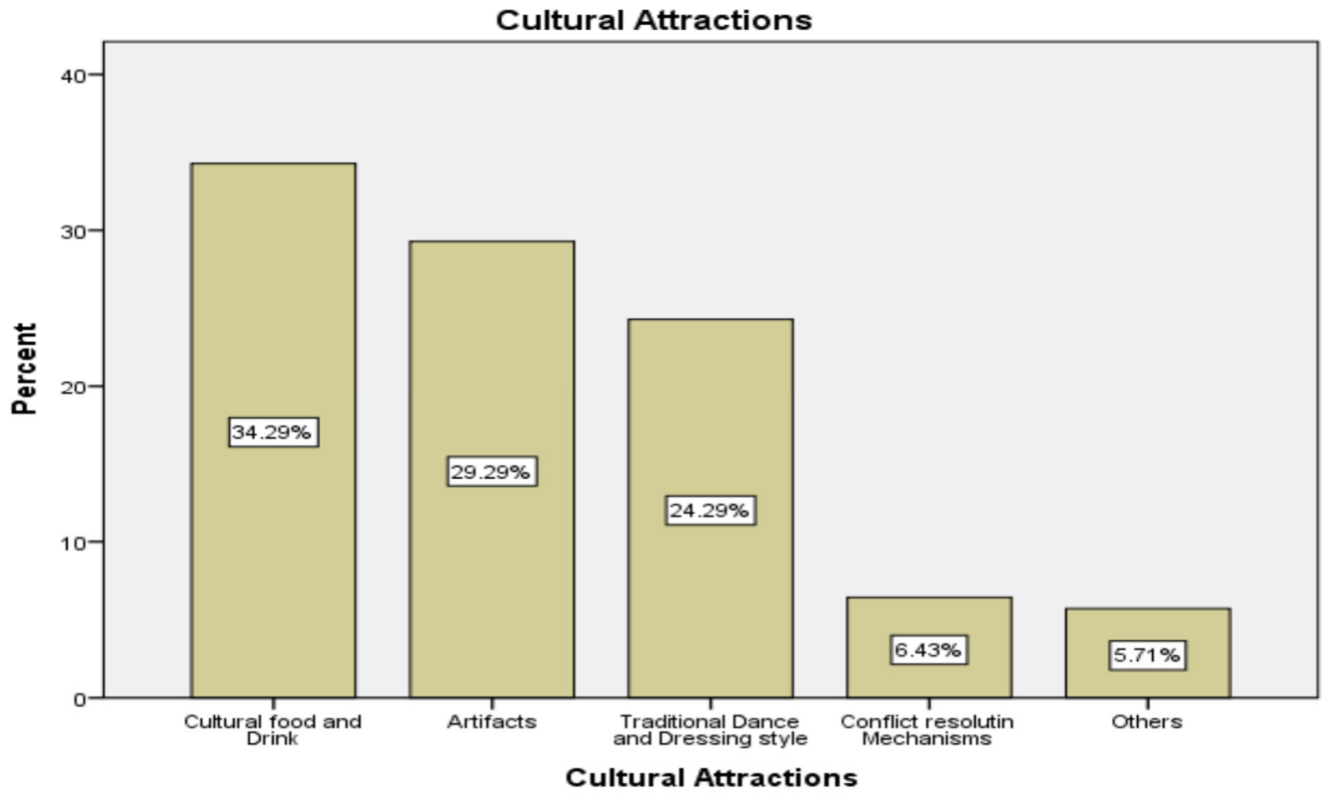

\subsubsection{Buna Qalaa}

Figure 8: Cultural resource for community-based ecotourism developments

According to community discussion and key informants interview, Buna Qalaa is seen as symbol of peace, agreement, and fertility of human beings and cattle. Buna Qala prepared from coffee bean ,the method of preparations is first wash the coffee bean and roasting it second by mixing plenty of butter with coffee bean then it could be eaten with spoon with family or neighbor. The Oromo prepare Buna Qalaa for ceremony purpose and for social purpose and as a source of food. It is also one of the most tasty and delicious meal of Oromo and an important ration during festivals and wedding. In Oromo culture, the family making Buna qalaa is shared the tasty buna qalaa with others or neighbors are obligatory, this can strength their partnership. The people's belief in the influence of its blessing is by saying 'kuma' which means 'thousand' and also means 'plenty'. The buna qalaa should be given to everyone in the house is the law. When they take the little cup with buna qalaa they say 'kuma horaa', 'kuma bobbasaa' meaning produce thousand (heads of cattle), lead out thousand (head of cattle) to graze, is must be said. Every time ones give buna qalaa to people, they bless, wish peace, health, prosperity to the giver.

\subsubsection{Cultural Food and Drink of Community Surrounding Haro Aba Diko Controlled Hunting Area}

According to respondents interview and community discussion, Haro Aba Diko Controlled Hunting Area Surrounded by Oromo ethnic group that practice both tangible and intangible cultural practices, cultural food and Drink is among tangible cultural resources that makes Haro Aba Diko Control Hunting Area an ideal place for developing diversified kind of community based ecotourism products for the sustainable benefit of the local community. During study period of time the researcher identified various cultural food and drinks these are:Buna Qalaa, Anchootee, Marqaa. Caccabsa, Maqinoo (irra Dibaa), Keenetoo, Bookaa, Daadhii (Figure 9).

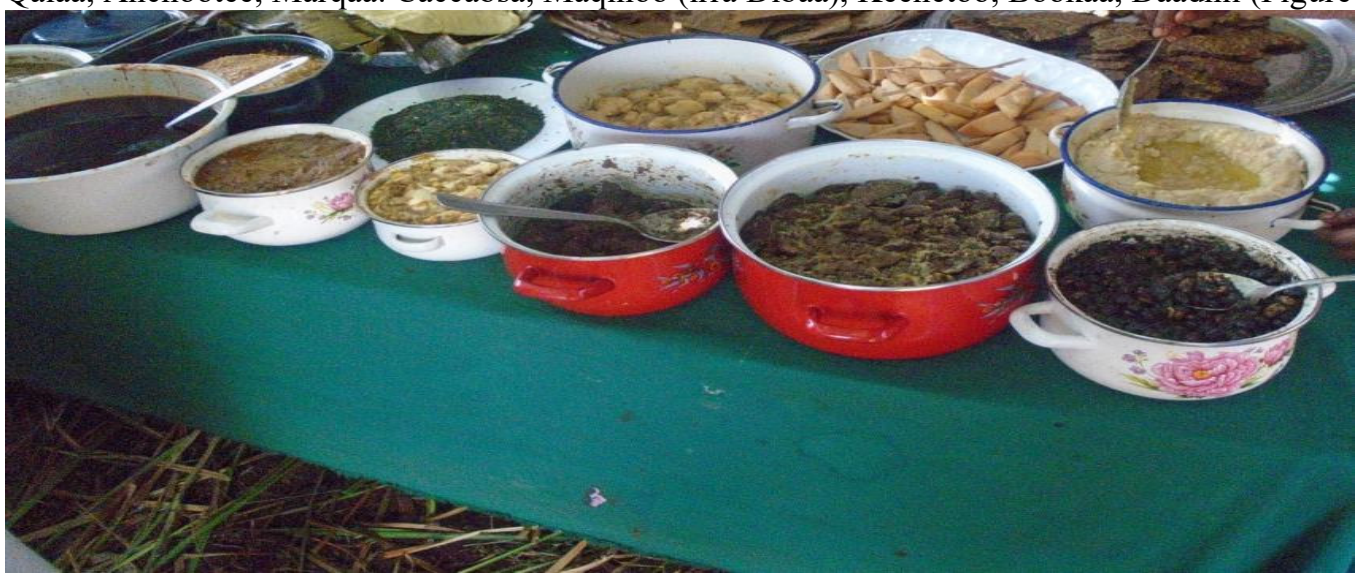

Figure 9: Traditional Food of Oromo ethnic group in Bunno Bedele Zone . 


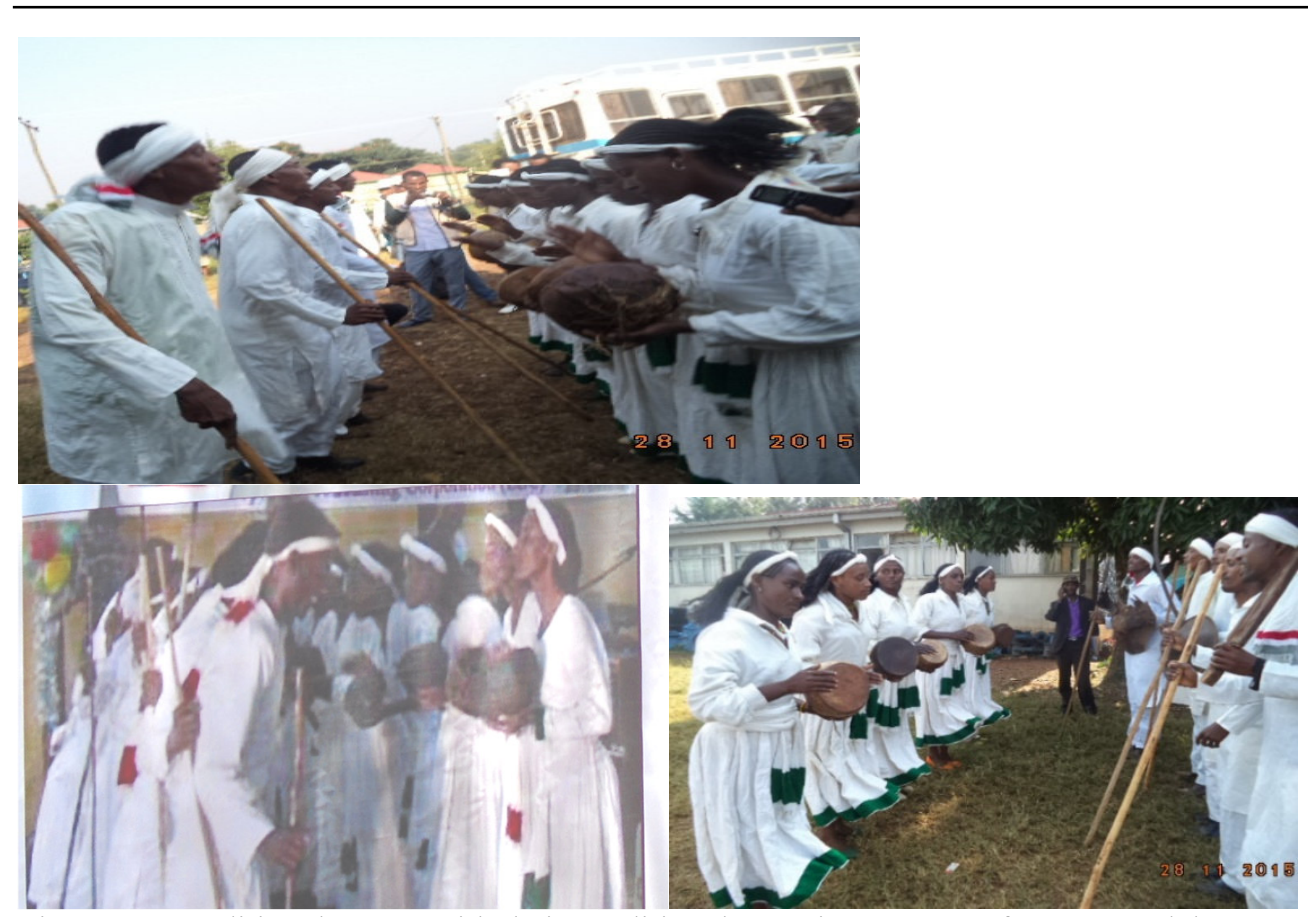

Figure 10: Traditional Dance with their Traditional Dressing System of Bunno Bedele Zone.

4.5. Challenges faced to develop community -based ecotourism at Haro Aba Diko Controlled Hunting Area. Figure (12) below showed, 57(40.7\%) of respondents mentioned that there is no awareness creation activity and training made by concerned body as well as there is no condition that drive community in community -based tourism activity. This indicates that Lack of knowledge and awareness can affect the participations of community in every aspect of conservations activities. Given that community participation is an essential element for community-based ecotourism development, lack of awareness and participations of community can affect the establishment and development of community based ecotourism. 27(19.3\%) of respondents described that potential degradations of flora and fauna through agricultural expansions and settlement within controlled hunting area was the main obstacles that hinders the establishment and development of community based ecotourism at Haro Aba Diko Controlled Hunting area. 18(12.9\%) of sampled respondents replied that lack of community social infrastructural service as another challenges that leads community towards resource degradations. This Indicated that the major challenges for establishing community based ecotourism in the study area is lack of community awareness about the concept and benefit of community based ecotourism and lack of tourism expertise to advertise and builds community capacity building in tourism developments in order to reduce destructions of potential resource needed for community- based ecotourism. Therefore to overcome such obstacles an urgent solution is needed through facilitating the mechanisms that participate community in every aspect of conservation activities like community-based ecotourism (Figure 12). It is in line with the studies Demeke and Verma (2014) and Alemayehu (2011) identified limited transportation and lodging facilities as a challenge for CBE in their study area. It also agreed with the study conducted by Ketema (2015) found that there was a conflict of interest on the ownership ofWonchi Crater Lake which is situated in Oromia Regional State, in central Ethiopia. 


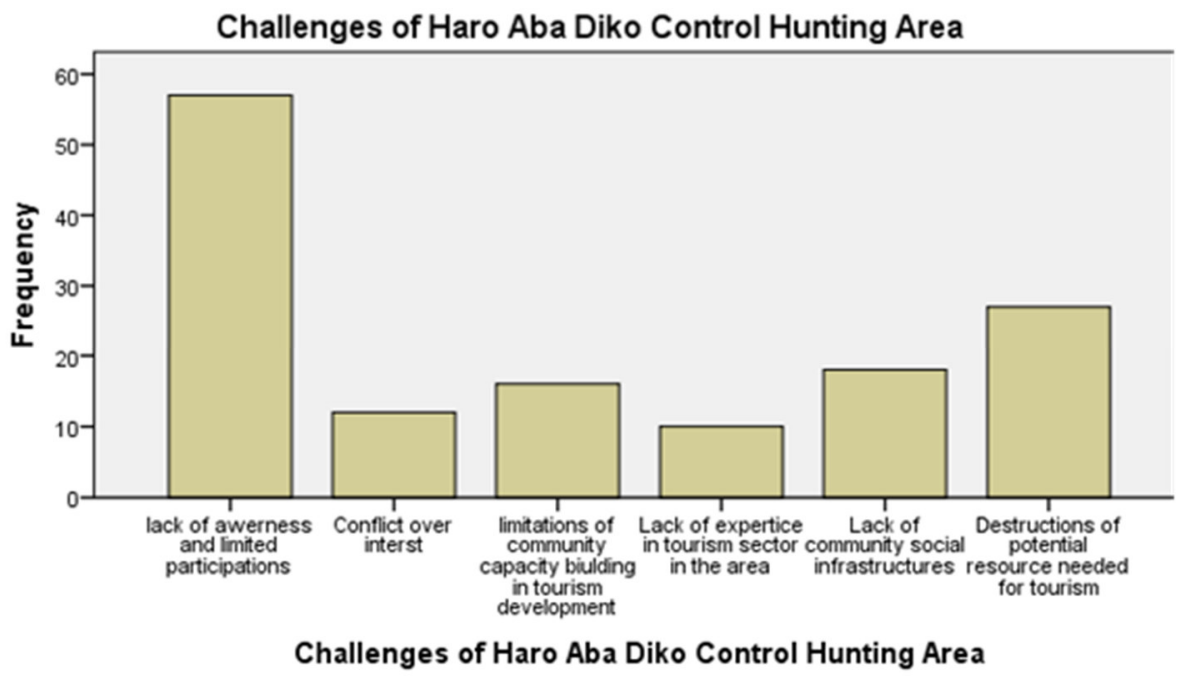

Figure 12: Responses of the respondent to the different challenges to establish community- based ecotourism( CBE).

\subsubsection{Lack of community Basic infrastructures}

Based on the survey result, majority of the respondents revealed that there was problem in social services in their locality (Table 2). $80.7 \%$ of respondents revealed that there was less number of schools while $19.3 \%$ of respondents mentioned that there was school service . Concerning the road service and transportation services, about $90.7 \%$ of respondents suggested that there was no good road service and adequate transport facilities. This indicated that lack of community social service and tourism infrastructures were the main challenges of the study area that also has an impact on formation of community- based ecotourism. This is agreed with the research conducted by Eshetie ,2012) ,reported that a lack of basic facilities such as electricity, an effective road network to and from Borena Sayint National Park and health stations, are major problems encountered. It supported by study conducted by (Berhanu ,2015) reported that poor health and accommodation services, very limited shopping, banking and postal services, the absence of all weather roads, and no wire service in all kebeles of Quara wereda except Gelegu town, are all huge problems requiring urgent support.

Table 2: Basic infrastructure of the community surrounding Haro Aba Diko Controlled Hunting area

Community social service

Is There school service in your locality

Is there road service for transport in your locality

Is There telecommunication service in your locality

Is There health care service in your locality

\begin{tabular}{llll}
\multicolumn{4}{l}{ Response } \\
Yes & $\%$ & No & $\%$ \\
27 & 19.3 & 113 & 80.7 \\
13 & 9.3 & 127 & 90.7 \\
15 & 10.7 & 125 & 89.3 \\
11 & 7.9 & 129 & 92.1
\end{tabular}

\subsubsection{Illegal hunting of wild life in Haro Aba Diko Controlled Hunting area}

Illegal hunting of wild life is another challenges faced Haro Aba Diko Controlled Hunting Area (HADCHA) to establish community-based ecotourism. The respondents mentioned that community surrounding the area not awared of about benefit gained from conserving wild life of the area. As a result some poaching of wild life observed in the area.The following figure shows poached buffalo by local poachers. This is agreed with (Habte, 2014) ; project on socio-economic analysis of community at debene didesa river. He reported that poaching of wild life is the major problems of Dabena Didesa river valley. This is because of the cultural myth that a man who failed to kill a buffalo is not fit to get married. Until recently trophies of buffaloes were available on rural roadsides, hanged on trees. Buffaloes have also migrated to the high-altitude forests of Jorgo-Wato Participatory Forest Management area, Oromia Regional State, where the number of individuals in each herd dramatically decreased (Figure 13) 

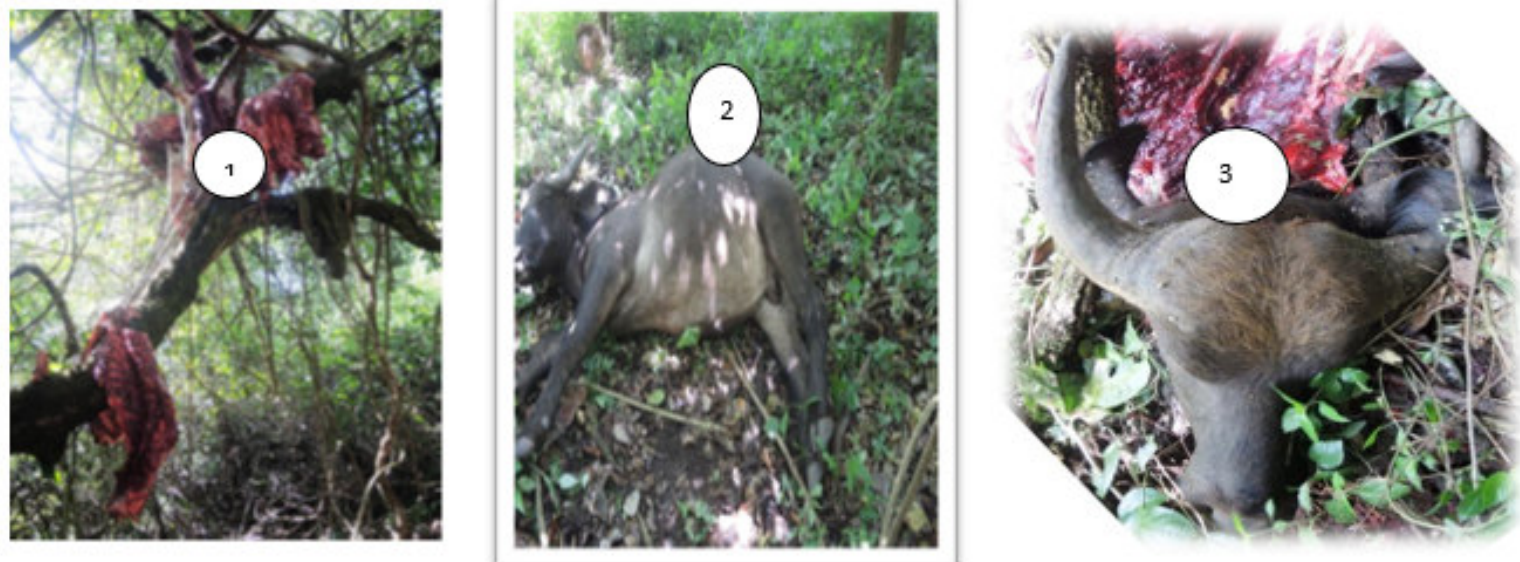

Figure 13: Poached and butchered unidentified subspecies of buffalo (S. caffer) on the bank of the Dabena River (tributary of the Didessa River), upper catchment of the Blue Nile (April 18, 2014). younger buffalo (3); older buffalo (2); butchered and carefully arranged for transport (1) and Trophies of Buffalo Hanged in the home(4). Source: Habte (2014).

\subsubsection{Lack of community knowledge and Awareness about community -based ecotourism}

Knowledge and the interest of community can affect the degree of community participations and ownership in tourism development. Majority (97.9\%) of sampled households, do not know what community based ecotourism mean. Only about $2.1 \%$ of sample respondents were familiar with the term community-based ecotourism. Concerning the second statement of (Table 10) the majority $(94.3 \%)$ of respondents mentioned that they did not taken any training on community based ecotourism, only about $5.7 \%$ of respondents replied as they had taken training on tourism issues in general and Community Based Ecotourism in different conference meeting (table 3). This shows awareness creation programes involving local community have not been conducted to raise the knowledge of people on the benefit of community based ecotourism. This is agreed with study conducted by Alemayehu (2011) most of the local people in his study area had no awareness about either ecotourism or community-based tourism, and they did not participate at any stage in park management decisions. It also supported by studies conducted by Demeke and Verma (2014), in their study in the Bale Mountains National Park, found that $71 \%$ of study respondents did not participate in any ecotourism activities although they wished to participate, which could be attributed to the limited flow of tourists in the study area.

Table 3: Response of respondents on Knowledge and awareness about community based ecotourism.

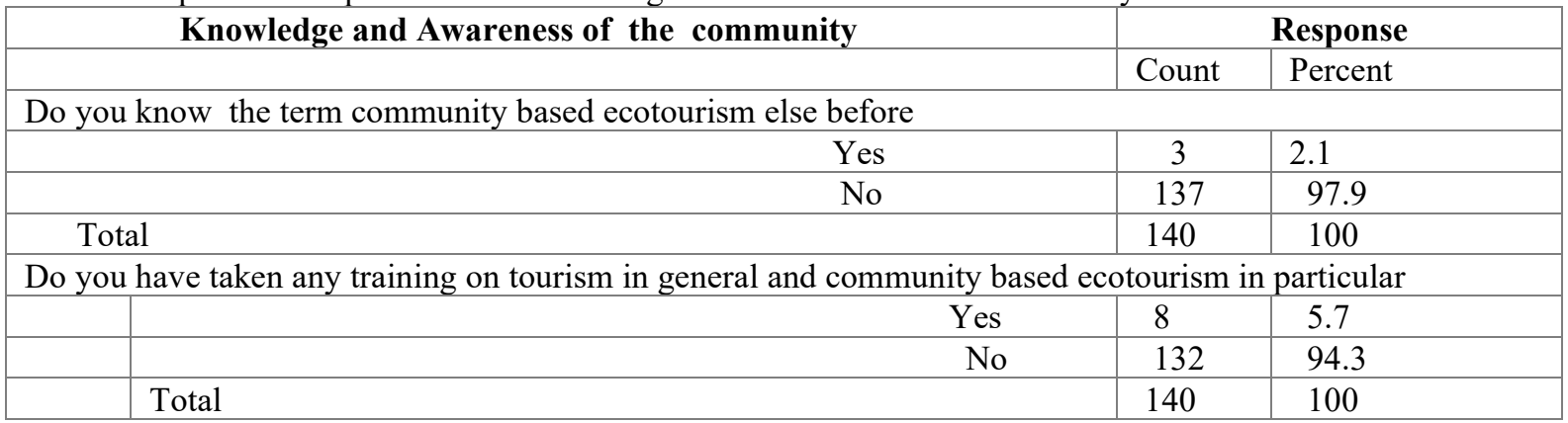

\subsubsection{Lack of Cooperation among Stakeholders}

According to focus group discussion with community leaders and interview with sample households, lack of cooperation between government body and community, lack of smooth relationship between community and concessioner of Haro Aba Diko Controlled Hunting Area were identified as constraints. They suggested that concessioner that owns the controlled hunting area was not benefiting community surrounding study area both socially and economically, rather the concessioner holds the area only for the purpose of own benefit. These finding is in line with the study conducted by Berhanu,(2013) in his study at Alatish national park. He revealed that there was weak integrations between different stacke holders and park office. It also agreed with studies conducted by ,Alemayehu (2011) and Aynalem (2013) reported that lack of stakeholder cooperation as a challenge for community based ecotourism development in their respective study areas.

\subsubsection{Lack of trained manpower in tourism professions}

Lack of skilled human resources is the major challenges facing the tourism industry in the country. According to focus group discussions and interview with forest and wild life expert and cultural and tourism expert they suggested that there were lack of ecotourism professionals in the area. To manage the Controlled Hunting Area effectively, there should at least be well trained 100 scouts, and one marketing and promotion expert, one natural 
resource management expert and two additional wildlife experts Berhanu, (2013).However the study area was only 8 scouts and lack marketing and promotion expert. This indicates that the study area lack trained manpower that promotes the potential resource of study area needed to establish community based ecotourism. This finding is supported by Alemayehu (2011), on his study at Awash national park. pointed out that there was no ecotourism expert or consultant who was in charge of ecotourism or community based ecotourism activities in Awash National Park as a result tourism aspects were not well managed.

\subsubsection{Limited Tourism Research and Development}

There was no research conducted in Haro Aba Diko Controlled Hunting (HADCHA) area concerning tourism in general and community based ecotourism in general except the research conducted by Habte,(2014 and 2015) concerning Pilot socio-economic analysis (SIA) of the planned protected area of the Dabena and Didessa River Valley and community educations to conserve biodiversity through the use of local resource persons. This indicated that the study area was not promoted and need further study to promote the potentials of the area as well as to facilitate the establishment of community based ecotourism for the seek of minimizing the degradations of resource and to provide income to the country in general and improvements of the livelihood of local community surrounding the area in particular.

\subsection{Perception and Expectations of Community towards Community Based Ecotourism}

The results obtained from respondents indicated that they have positive attitudes for establishing community based ecotourism in Haro Aba Diko Controlled Hunting Area.

Table 4: Perception of society about community based ecotourism

Attitudes and Expectations of community Rating Scale

towards community based ecotourism Rating Scale

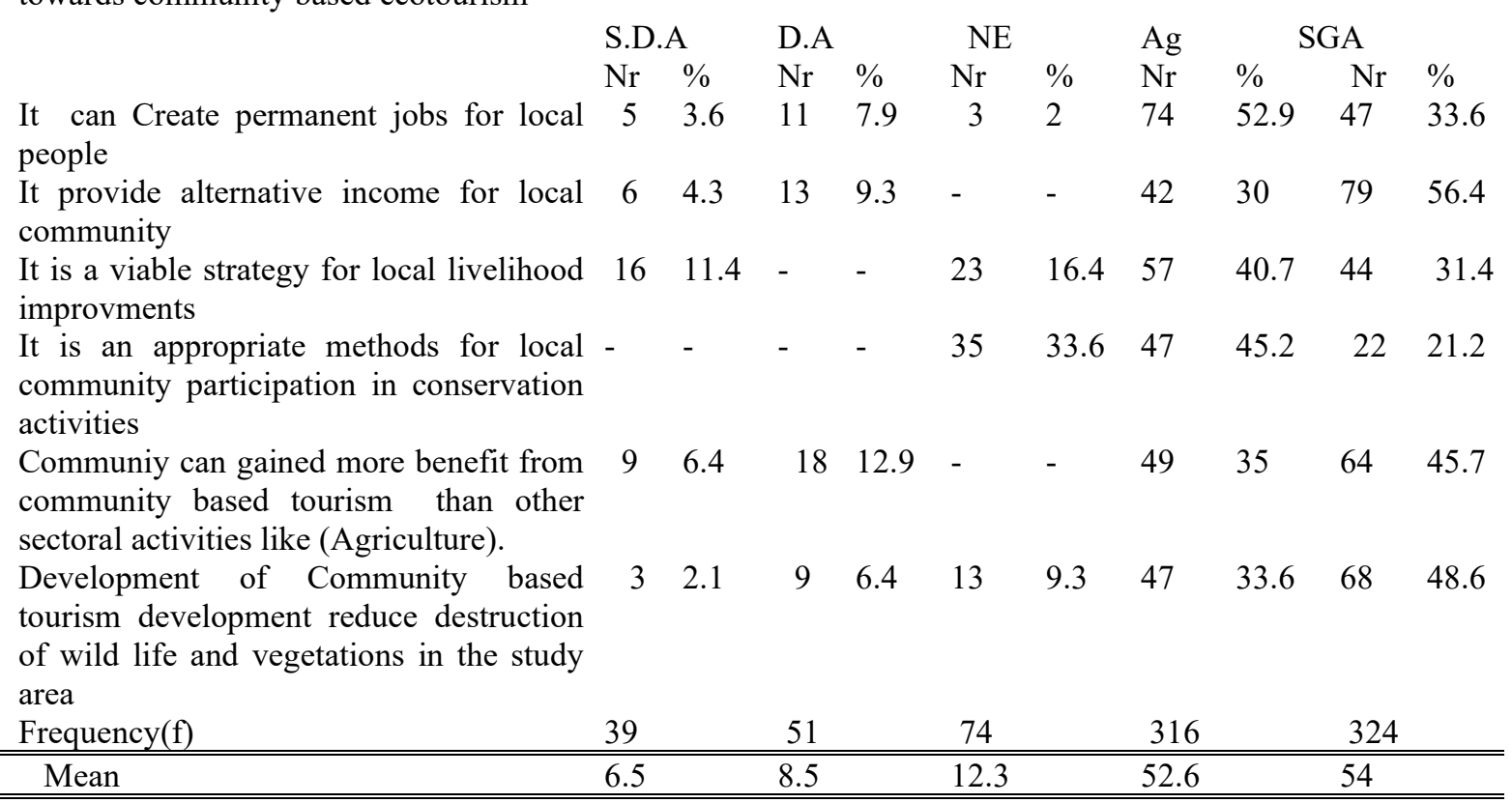

Key: $\mathrm{SDA}=$ Strongly disagree, $\mathrm{DS}=$ Disagree $\mathrm{NE}=$ not expected $\mathrm{Ag}=\mathrm{Agree} \mathrm{SAG}=$ Strongly agree $\mathrm{Nr}=\mathrm{Number}$ of respondents.

If the community is not interested in Community- based ecotourism development, the development of Community-based ecotourism will fail, given that community participation is a crucial element of Communitybased ecotourism. The survey result of respondents showed that Both frequency and mean show increament. As it is stated in table above $86.5 \%$ of the respondents belived that community based establishment in Haro Aba Diko Controlled Hunting Area create permanent jobs for local community surrounding the area in contrast to the majority respondents only $11.5 \%$ of the total respondents disagreed to the raised questions. In the same ways only $13.6 \%$ of respondents feel that community- based ecotourism establishment not provide alternative income .But $86.4 \%$ of respondents agreed that the establishment of community- based ecotourism in the study area provide alternative income to local community.

From the total participant majority, $66.4 \%$ of them agreed that community based ecotourism activities are the best options for participating community in conservations activities and $35 \%$ of total respondents were unable to decide their answer to the raised questions. $80.7 \%$ agreed that community based ecotourism can provide more benefit for community than other sectoral activities like agriculture. Regarding loss of wild life and forest the majority of respondents $82.2 \%$ agreed that development of community- based ecotourism is the best alternative 
for reductions of wild life and forest in Haro Aba Diko Control Hunting area. In contrast to this only $8.5 \%$ of total respondents disagree with raised questions (Table 4).The majority of respondents has positive attitudes and expectations towards community based ecotourism establishment in Haro Aba Diko Controlled Hunting area.This result contradicts with the study conducted by Gebeyehu,(2011) on practice, challenges and opportunities of Community-based ecotourism development in Meket Woreda,North wollo, reported that most of the households are not interested with the new alternative livelihood options community based ecotourism.

\section{CONCLUSIONS AND RECOMMENDATIONS}

This thesis attempts to examine the potentials and challenges of Community Based Ecotourism in Haro Aba Diko Controlled Hunting area,Bunno Beddele zone,south western Ethiopia.The result of the study showed that Controlled Hunting area has huge atractive natural and cultural potential resource needed for community based ecotourism development. These includes Dabena and Didessa river diversity of fauna such as African Buffalo (Syncerus caffer), Bush Pig,( Potamochoerus larvatus) Black and white monkey(Colobus guereza), Common bush Buck(Tragelaphus scriptus), Water Buck(Kobus ellipsiprymnus ) Plain Zebra (Equus quagga,) Blue monkey (Cercopiticus mitis) and attractive forest found in the study area, and cultural resource of the areas are valuable opportunities that empower development of community based ecotourism, However having these potential resource community- based ecotourism establishment is constrained by the following factors:

$\checkmark \quad$ Lack of community knowledge about community based ecotourism

$\checkmark$ Limitations in community capacity building from government organizations

$\checkmark$ Lack of community social infrastructures that had lead local community to destructions potential resource of study area.

$\checkmark \quad$ Lack of promotions of the study area potential resource for tourism

$\checkmark$ Lack of cooperation's among community and governmental and private organizations to discuss on constraints and opportunity of the study area.

$\checkmark \quad$ Lack of tourism professionals in the study area that facilitate the promotions and marketing of potential resource of the study area.

$\checkmark$ Human induced pressure like illegal hunting of wildlife,settlement withn control hunting area and conversions of forest land to agricultural land are the obstacles that hinders establishment of community based ecotourism in Haro Aba Diko Controlled Hunting area.

To establish the community based ecotourism and minimizing the challenges, the following recommendations were forwarded.

* It has to have broader awareness creation program for the wider communities towards the tourism business and its impacts on their lives by providing adequate trainings.

\# To ensure community-based ecotourism establishment in the study area, local communities must undergo various capability-building programs. This in turn, enables the communities to provide them with skills which are needed to manage the tourism activities that are going to be established in Haro Aba Diko Controlled Hunting area.

\& Local community social infrastructural service should be provided in order to reduce community dependence on controlled hunting area.

* A further investigation is needed to identify and promote potential resource of Controlled Hunting area.

\section{ACKNOWLEDGEMENT}

Authors acknowledge Mettu University for funding the research project., it is my pleasure to express my heartfelt appreciation and special gratitude to my major research advisor Dr.Fanuel Kebede and Co-Advisor Dr.Dereje Denu for their un reserved support and encouragement my gratitude also goes to the study village communities for their kind support in supporting this study.

\section{CONFLICT OF INTERESTS}

The authors have not declared any conflict of interests.

\section{REFERENCES}

Ambelu G (2011).Practices, Challenges and Opportunities of Community Based Ecotourism Development in Meket Woreda North Wollo; Unpublished Thesis Addis Ababa University

Berhanu K (2013).Opportunities and Challenges for Wildlife Conservation and Ecotourism Development of Alatish National Park; Northwest Ethiopia; unpublished thesis, University of Gondar.

Berhanu W (2003).The role of Tourism in the economic development of local communities in Ethiopia: A cased study of Gerealta \&Axum areas of Tigray administrative region.

Bires Z (2014).Challenges and Prospects of Community Based Ecotourism Development In Lake Zengena, BanjaWoreda, Awi Nationility Administration; unpublished thesis, Addis Ababa University. 
Birtukan A (2018). Atinkut pitfalls of tourism development in ethiopia: a case of bahir dar town and its surroundings, a historical perspective, Vol.6, No.1, pp.11-28.

Choi HC and Murray I (2010). .Residents Attitudes toward Sustainable Community Tourism, Journal of Sustainable Tourism 18 (4): 575-594

Daniel A (2011). Challenges and Opportunities for the Establishment of Communitybased Ecotourism in the Awash National Park Area, Unpublished thesis, Addis Ababa University.

Demeke A \& Ashok V (2013). Local attitude towards environmental conservation and ecotourism in BMNP, Journal of Environmental Science and Water Resources, 2(8)

Eshetie W (2012).Potentials, Challenges and Opportunities for Community Based Ecotourism Development at Borena Sayint National Park; South Wello, Unpublished thesis University of Gondar.

Fariborz A, Ma'rof R and Sarjit G (2009). Dimensions of Community Capacity Building: A review of its Implications in Tourism Development. Journal of American Science. 5(8).

Faulkner B and Tideswell C (2010). A Framework for Monitoring Community Impacts of Tourism, Journal of Sustainable Tourism 5(1): 3-28.

Gabeyehu A G (2011).Practices, Challenges and Opportunities of Community Based Ecotourism Development in Meket Woreda North Wollo; Unpublished Thesis Addis Ababa University

Habte J (2014, 2015). Pilot socio-economic analysis (SIA) of the planned protected area of the Dabena Didessa River Valley, south Western Oromia Region, Ethiopia and Community Education to Conserve Wildlife in the Didessa River Valley, south Western Ethiopia -March 21-22, 2015 Bahirdar University, Bahirdar, Ethiopia

Henze BP (2007b). Ecotourism in Ethiopia: Opportunities and ideas. Conference of IDR/AAU.

Kiss A (2004). Is community-based ecotourism a good use of biodiversity conservation funds? TRENDS in Ecology and Evolution. 19(5): 232-236.

LDMA (2010). Annual progress report, Livestock Development and Marketing Agency, (LDMA). Ilu Aba Bora Zone Department of Agriculture. Mettu, Ethiopia.

Michael K (2003). "Ecotourism, environmental preservation and conflicts over natural resources "Horizontes Antropológicos, 20:185-203.

Ministry of Culture and Tourism. (2009). Federal Democratic Republic of Ethiopia Tourism Development Policy, Addis Ababa.

MOCT 2006) .Ministry of Culture and Tourism of Ethiopia.Unpublished: Tourism statistics bulletin No.8.

Mulugeta A (2011).Community based ecotourism as a tool for biodiversity conservations and sustainable development .Semien mountain national park,Addis abab university,

Sewnet T (2017). Challenges and Opportunities for Community Based Ecotourism Development in Ethiopia. African Journal of Hospitality, Tourism and Leisure, Volume 6 (3)

Sintayehu A (2013).Tourism Potentials and Community-Based Ecotourism Development, a Case of Choke Mountain and its Environs, Ethiopia, Journal of Hospitality and Management Tourism,6,(4).

Temesgen K (2014).The Tourism Industry in Ethiopia. Mekelle University, Ethiopia

Teresa D (2015).Development of community based ecotourism in Wenchi Crater Lake, Ethiopia: Challenges and prospects, Journal of Hospitality and Management Tourism, Vol. 6(4), pp. 39-46

The International Ecotourism Society (2012). Ecotourism development;

TIES (2015).Uniting conservation, communities and sustainable travel

World Tourism Organization (2007). Tourism Market Trends, Africa. Madrid, Spain

Maggie Wilder (2016). An assessment of ecotourism as an effective tool for sustainable forest management: The case of Adaba-Dodola, Ethiopia.

Mulugeta Asteray (2011). Community Based Ecotourism (CBET) as a Tool for Biodiversity Conservation and Sustainable Development: A Case Study on the Simien Mountains National Park, Master thesis. (Unpublished), AA.

Mulugeta, Fisseha. (2012). The fundamentals of community based ecotourism development in Ethiopia, Addis Ababa, Ethiopia.

International Ecotourism Society (IES). (2016). Ecotourism definition. Retrieved from the web site of the International Ecotourism Society. https:/www.ecotourism.org/book/ecotourism-definition

Christian, S. (2012). Ecotourism in Lake Tana region, Ethiopia potentials for the implementation of communitybased ecotourism, A Master's Thesis. (Unpublished

Aregawi, K. (2016). Challenges and prospects of ecotourism development the case of kelala woreda, in south wollo zone, amhara region, Ethiopia, Master Thesis. (unpublished),AA. 